\title{
A nyaki dissectiók onkológiai hozamának maximalizálása a sebészi morbiditás egyidejü minimalizálása mellett
}

\author{
Háromi István dr. ${ }^{1}$ - Gerlinger Imre dr. ${ }^{1}$ - Lujber László dr. ${ }^{1}$ \\ Lőrincz Balázs Bendegúz dr. ${ }^{2}$
}

\author{
${ }^{1}$ Pécsi Tudományegyetem, Általános Orvostudományi Kar, Klinikai Központ, \\ Fül-Orr-Gégészeti és Fej-Nyak Sebészeti Klinika, Pécs \\ ${ }^{2}$ Hamburg-Eppendorf Egyetemi Klinikai Központ, Fül-Orr-Gégészeti, Fej-Nyak Sebészeti és Onkológiai Klinika, \\ Hamburg
}

\begin{abstract}
A regionális nyaki lymphadenectomia - elterjedt nevén nyaki dissectio - a fej-nyaki tumorsebészet fontos alapmútéte. Ezen műtét 110 éves evolúciója során a különböző iskolák, nevezéktanok és mútéti technikák keveredése nyomán olyan mértékû zavar alakult ki az irodalomban és a mindennapi szakmai életben, amely szinte lehetetlenné teszi a sebészi és onkológiai eredmények standardizálását és objektív összehasonlítását. Ezt a helyzetet kísérlik meg a szerzők jelen összefoglaló munkájukban közérthetően tisztázni, a multidiszciplináris fej-nyaki terápiás döntésekben részt vevő kollégák kommunikációját megkönnyítendő annak érdekében, hogy a fej-nyaki tumoros betegek számára minden esetben optimális terápiás döntés szülessék. A közlemény történeti és irodalmi áttekintést ad, valamint ismerteti a két legelterjedtebb műtéti technika eredményeinek statisztikai összehasonlítását. A mútéti technika megválasztása szignifikáns hatással van az onkológiai hozamra. A megfelelő sebészi koncepció az onkológiai haszon maximalizálása mellett a betegek életminőségét a lehető legkisebb mértékben befolyásolja, egyrészt a primer sebészi terápiás morbiditás csökkentése, másrészt az adjuváns indikációk optimalizálása révén. Orv. Hetil., 2016, 157(47), 1871-1879.
\end{abstract}

Kulcsszavak: fej-nyaki daganatok, nyaki dissectio, nyirokcsomóhozam, nyaki fascia, sebészi stádiummeghatározás

\section{Maximizing nodal yield while minimizing surgical morbidity: the appropriate neck dissection}

\begin{abstract}
Cervical regional lymphadenectomy, also known as neck dissection, is a fundamental procedure in head and neck surgery. Its evolution over 110 years resulted in a great deal of confusion in the literature and in clinical practice, due to the heterogenicity in training, classification and surgical techniques, which makes outcomes comparability virtually impossible. The authors aim to clarify this situation in a structured manner, in order to facilitate communication among all specialists involved in multidisciplinary head and neck cancer care. The ultimate goal is to make sure that each and every head and neck cancer patient receives their optimal treatment. Review of the history and literature with statistical comparison of the two mainstraim methods regarding their nodal yield results. The applied surgical technique has a significant impact on nodal yield. An appropriate surgical concept achieves maximum oncologic benefit, minimum surgical morbidity with optimized adjuvant indications.
\end{abstract}

Keywords: head and neck cancer, neck dissection, nodal yield, cervical fascia, surgical staging

Háromi, I., Gerlinger, I., Lujber, L., Lörincz, B. B. [Maximizing nodal yield while minimizing surgical morbidity: the appropriate neck dissection]. Orv. Hetil., 2016, 157(47), 1871-1879.

(Beérkezett: 2016. július 20.; elfogadva: 2016. szeptember 20.) 


\section{Rövidítések}

$\mathrm{CI}=$ konfidenciaintervallum; CRT = kemoradioterápia; cTNM = klinikai tumorstádium-meghatározás; DÖSAK = Deutsch-Österreichisch-Schweizerischer Arbeitskreis für Tumoren im Kiefer- und Gesichtsbereich; ECS, ECE = nyirokcsomó-metasztázis extrakapszuláris terjedése; $\mathrm{LNR}=$ lymph node ratio: a hisztológiailag érintettnek bizonyult nyirokcsomók számának és az összes eltávolított nyirokcsomók számának hányadosa; pTNM = kórszövettani tumorstádium-meghatározás; RTOG = Radiation Therapy Oncology Group; TOS = transorális sebészet

Az onkológiai sebészetben ismert tény, hogy a regionális lymphadenectomiák során begyújtött abszolút nyirokcsomószám, az úgynevezett nyirokcsomóbozam (nodal yield) független prognosztikai faktor a vastagbél [1,2], a rectum [3], a húgyhólyag [4-6], a prosztata [7], a hímvessző [8], a nyelőcső [9], a gyomor [10] és az emlő daganatai esetében [11]. Ezen prognosztikai faktor alkalmazható a kimutatható nyirokcsomó-metasztázis nélküli esetekre is, azaz független a nyirokcsomók metasztatikus érintettségétől [12]. Fentiek fényében más szakterületeken már egységes követelményrendszerek határozzák meg a regionális lymphadenectomiák során begyưjtendő nyirokcsomók minimális számát, amely alatt az aktuális specimen alkalmatlannak minősül stádiummeghatározásra. Hasonló számbeli küszöb meghatározása a nyaki dissectiók esetén is célszerünek tünik.

A nyirokcsomóhozam prognózisra gyakorolt hatása hasonlónak bizonyult a papillaris pajzsmirigyrákok [13, 14], valamint a szájüreg $[12,15-18]$, az oropharynx [17] és a hypopharynx [17, 19] laphámrákjai esetében is. Egy, a közelmúltban megjelent multicentrikus tanulmány megerősítette a nyirokcsomóhozam független prognosztikai szerepét a cN0 nyaki stádiumú szájüregi laphámrák miatt elektív és szelektív nyaki dissectión átesett betegeknél is [18].

Figyelemre méltó és jelzésértékű fejlemény, hogy a fejnyaki onkológia terén a legújabb - fơleg tengerentúli klinikai tanulmányok már a beválasztási kritériumok közé sorolják a nyaki dissectiók nyirokcsomóhozamát. A Radiation Therapy Oncology Group (RTOG) RTOG1221 számú, a közelmúltban lezárt multicentrikus vizsgálata, amely a szájgarati laphámrákok primer kemoradioterápiás (CRT), illetve primer transoralis sebészi (TOS) terápiáját hasonlítja össze, a sebészi ágba csak olyan betegeket engedett beválasztani, akiknél a nyaki dissectio során minimum 15 nyirokcsomó eltávolításra került. (Ideális számként 20 feletti nyirokcsomót ad meg az RTOG-1221 protokoll; a 15 és 20 közötti értéket minor devianciaként jegyzik, míg a 15 alatti nyirokcsomóhozamú betegek nem vesznek részt a statisztikai kiértékelésben.)

A német nyelvü országokban szintén jelenleg zajló, a DÖSAK (Deutsch-Österreichisch-Schweizerischer Arbeitskreis für Tumoren im Kiefer- und Gesichtsbereich) által koordinált úgynevezett pNl-Studie a szájüregi és szájgarati pT1/pT2, pN1, ECS-negatív, cM0 laphámrákok primer sebészi terápiájának eredményét hasonlítja össze adjuváns sugárterápiával, illetve a nélkül. A pNlStudie beválasztási kritériumai között nem szerepel a nyirokcsomóhozam. Az eddigi adatok alapján azonban úgy látszik, hogy az alacsony nyirokcsomó-hozamú nyaki dissectión átesett betegeknél gyakrabban jelentkezik igen korai N-recidíva, amely feltehetően nem valódi recidíva, hanem valójában residualis betegség, tehát olyan mikrometasztázis későbbi klinikai manifesztációja, amely a nem kielégítő onkológiai teljességü nyaki dissectio nyomán maradt hátra a primer sebészi kezelés során. Jelen közlemény utolsó szerzője ennek alapján kezdeményezte a pN1-Studie protokolljának utólagos felülvizsgálatát, illetve módosítását.

Fentieken kívül a nyirokcsomóhozam hasznos paraméterként szolgálhat a sebészi technika kivitelezésének és a sebészi kezelés onkológiai megbízhatóságának értékelésében. Ezen a területen a sebészi technikák bizonyos szintû standardizálása is szükséges lesz, lehetővé téve a megbízható reprodukálhatóságot, valamint a sebészi és nem sebészi (konzervatív) terápiás modalitások statisztikai összehasonlíthatóságát.

Jelen vizsgálatban - a nyirokcsomóhozam más szerzők által leírt, fent részletezett onkológiai jelentőségéből kiindulva - célunk az alkalmazott sebészi koncepció és dissectiós technika nyirokcsomóhozamra kifejtett hatásának vizsgálata volt. Ez az első tanulmány az irodalomban, amely egy adott dissectiós technikából levezethető, statisztikailag szignifikáns előnyt igazol a nyirokcsomóhozam tekintetében.

Elsődleges célunk a nyirokcsomóhozam maximalizálása volt, a terápiás morbiditás egyidejű minimalizálása mellett. Ez a gyakorlatban az összes anatómiai struktúra megőrzését jelenti a nyirok- és zsírszöveten kívül. Egyfelől egyetlen struktúra feláldozása sem lehet szükséges a magasabb nyirokcsomóhozam elérése céljából, másfelól azonban a fontos képletek megőrzése sem veszélyeztetheti a hozamot [20]. Ennek a két követelménynek egyszerre leginkább Osvaldo Suárez (Córdoba, Argentína, 1962 ) eredeti funkcionális koncepciója tesz eleget, amelyet Javier Gavilán korszerúsített és helyezett új megvilágításba „Functional and selective neck dissection” [21] címü, 2002-ben megjelent könyvében. Ezen funkcionális koncepció a gyakorlatba logikusan átültethető, standardizált, lépésről lépésre követhető, jól tanítható sebészi elvet követ, amelynek központjában a fasciarétegek - mint nyaki onkológiai barrierek - mentén történő funkcionális anatómiai dissectio áll. Az ebből levezetett sebészi technika könnyen elsajátítható és megbízhatóan standardizálható, illetve a koncepció helyes megértése és ismerete mellett bármely fej-nyak sebész által biztonsággal reprodukálható [22]. 


\section{Onkológiai sebészi koncepció}

Jelen értelmezésben, Osvaldo Suárez eredeti leírásának megfelelően, a funkcionális kifejezés kizárólag a nyaki fascia onkológiai barrier funkciójára vonatkozik, és nem tévesztendő össze a megőrizni kívánt képletek (elsősorban a vena jugularis interna, a nervus accessorius és a musculus sternocleidomastoideus) funkciójával. A funkcionális nyaki dissectio semmilyen tekintetben nem szinonimája sem a szelektív, sem a módosított radikális nyaki dissectiónak [23].

A funkcionális nyaki dissectio egy sebészi koncepciót jelöl, tekintet nélkül a mútét kiterjedésére, illetve az eltávolított nyirokcsomó-régiók számára. Ez utóbbi szempontból megkülönböztetünk szelektív, illetve komprehenzív nyaki dissectiókat, ennek megfelelően az eltávolított régiók számától függően beszélhetünk funkcionális szelektio (kevesebb mint öt nyaki régiót tartalmazó), valamint funkcionális komprehenzív (mind az öt nyaki régiót felölelő) nyaki dissectióról. Az indikáció szempontjából - a klinikai N stádiumtól függően - a nyaki dissectio lehet elektív (azaz profilaktikus), illetve terápiás célú, ennek megfelelően definiálhatunk elektiven végzett funkcionális szelektív vagy éppen terápiásan végzett funkcionális komprehenzív nyaki dissectiókat. Didaktikai okokból a lent tárgyalt mútéti módszerre a továbbiakban ,fasciakifejtéses” vagy horizontális technikaként utalunk, tudatosan mellőzve a széles körben hamisan használt fogalomként elterjedt és általánosan tévesen értelmezett funkcionális nyaki dissectio kifejezést.

\section{Módszer}

A horizontális irányú, „fasciakifejtéses” technika - a régóta alkalmazott vertikális dissectiós technika mellett klinikánkon való bevezetését követően, 2011. február és 2013. március között (26 hónap) prospektív klinikopatológiai adatgyújtést végeztünk nyaki dissectión átesett betegeinknél. A tanulmány keretein belül 150 beteg adatai kerültek kiértékelésre a kétféle sebészi technika és azok nyirokcsomóhozamra gyakorolt lehetséges hatásának összehasonlítása céljából, összesen 223 nyaki dissectiót vizsgálva (73 kétoldali mútét történt).

\section{Betegek}

82 betegnél a standardizált, horizontális irányú, „fasciakifejtéses" dissectiós technikával történt mütéti beavatkozás (1. csoport), míg 68 beteg a nyaki fasciarétegek következetes „kifejtése” nélküli, a korábban már széleskörúen alkalmazott caudocranialis irányú dissectión esett át (2. csoport). A specimenek mindkét csoportban „en bloc” kerültek eltávolításra. A hisztopatológiai vizsgálatra való átadás előtt a sebész az egyes nyaki régiókat különválasztotta egymástól az orientálás kórszövettani megkönnyítése céljából $[24,25]$. Az egyes nyaki régiók pontos megjelölése a legfontosabb minőség-ellenőrzési szempont, amely könnyen elvégezhető egy jelölt parafatáblára való rögzítés vagy az egyes nyirokcsomórégiók szeparált tégelyekben való beküldése segítségével.

A nyaki dissecatumokat minden egyes betegnél ugyanazok a patológusok dolgozták fel és értékelték ki, standardizált, elöre meghatározott módon. A patológusokat nem tájékoztattuk az egyes esetekben alkalmazott dissectiós technikáról. A prospektív adatgyưjéés tartalmazta a klinikai és a patológiai stádiumot, a nyaki dissectio típusát, a dissectio konkrét nyaki régiókra való kiterjedését, a betegek nemét, az oldaliságot, a nyaki dissectio technikáját, a begyújtött összes nyirokcsomók számát (nodal yield), a régiónkénti nyirokcsomószámot, valamint a nyirokcsomóarányt (lymph node ratio - LNR: a hisztológiailag áttétesnek bizonyult nyirokcsomók számának és az összes eltávolított nyirokcsomók számának hányadosa).

\section{Beválasztási és kizárási kritériumok}

Minden, az adott időintervallumban végzett, legalább három nyaki régiót bármely kombinációban érintő szelektív, illetve komprehenzív nyaki dissectio beválasztásra került. Az N0 klinikai stádiummal jellemzett esetek mellett $\mathrm{N}+$ esetek is helyet kaptak, amennyiben az utóbbiak esetében nem volt klinikailag vagy radiológiailag kimutatható extrakapszuláris terjedésre (ECS, ECE) utaló jel, amely a fasciarétegek menti standardizált dissectiót esetlegesen kivitelezhetetlenné tette volna. A vena jugularis interna, a nervus accessorius és a musculus sternocleidomastoideus minden esetben megörzésre került. Az N0 és $\mathrm{N}+$ esetek eloszlása mindkét csoportban azonos volt. A nyaki dissectiók kiterjedése a primer tumor elhelyezkedésétől függően az I-III., az I-IV., az I-V., a II-IV. és a II-V. régiókat foglalta magában. A primer tumorok (szövettanilag laphámrákok) stádiumai és lokalizációi az alábbiak voltak: T1 és T2 szájüreg (szelektív nyaki dissectio az I-III., illetve az I-IV. régiókra kiterjedően, vagy komprehenzív nyaki dissectio); T1 és T2 oropharynx (szelektív nyaki dissectio a II-IV., illetve az I-IV. régiókra kiterjedően, vagy komprehenzív nyaki dissectio); $\mathrm{Tl}$, T2, T3 hypopharynx és gége (szelektív nyaki dissectio a II-IV. régiókra kiterjedően, illetve komprehenzív nyaki dissectio).

A klinikailag, illetve radiológiailag extrakapszuláris terjedést mutató vagy arra gyanús esetek nem szerepeltek a beválasztott beteganyagban, tekintve, hogy ezen nyaki áttétek jelenléte technikailag kizárta volna a ,fasciakifejtéses” technika standardizált elvégzését. Szintén kizárásra kerültek azok a betegek is, akiknek anamnézisében megelőző nyaki mütét vagy sugárkezelés szerepelt. Jelen tanulmányban a salvage mútéti indikáció is kizárási kritériumként szerepelt.

\section{Mütéti technika}

A nyirokcsomóhozam kvantitatív maximalizálása a funkcionális dissectio kvalitatív koncepciója révén érhető el, 

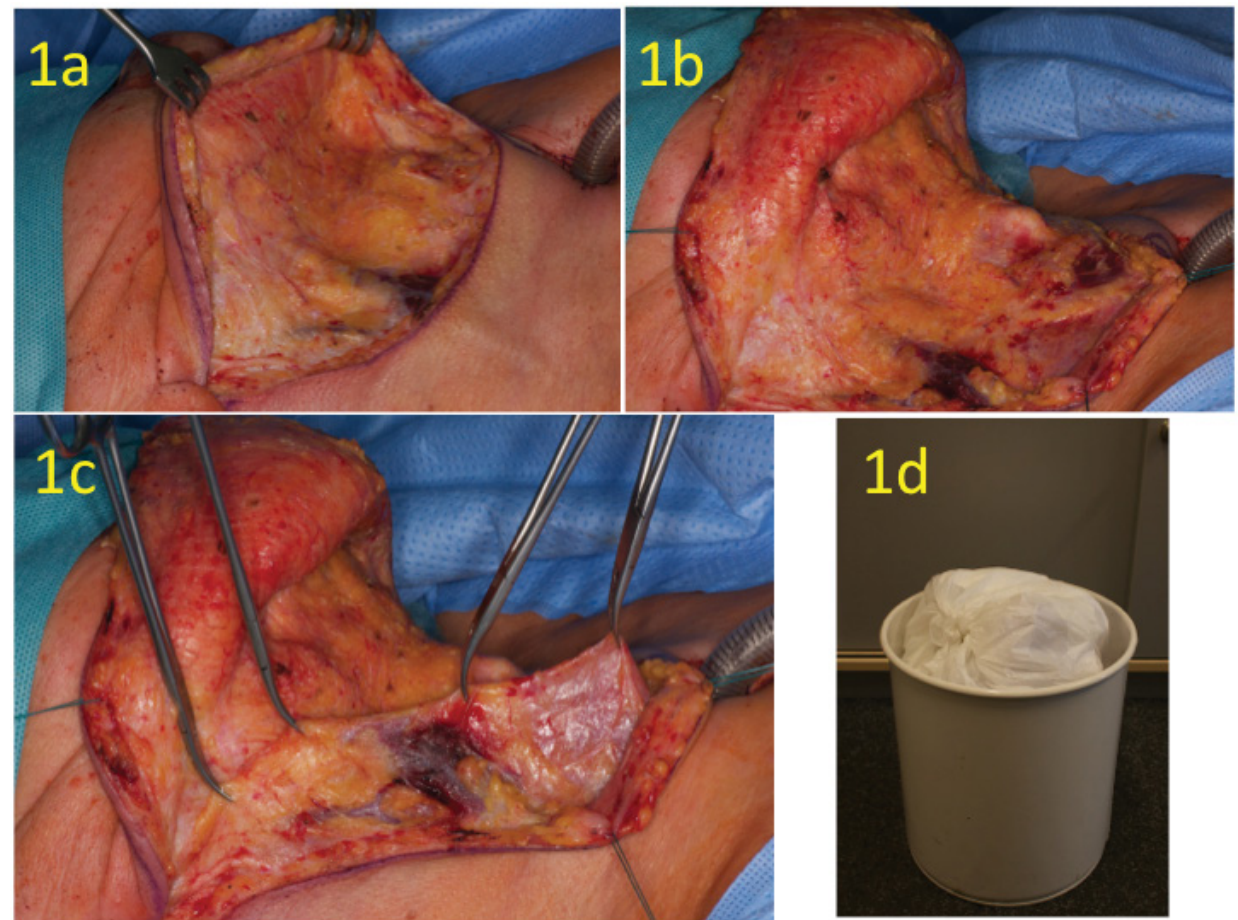

1. ábra

a) A bőr-platysma lebeny felemelése cranialisan. b) A bőr-platysma lebeny felemelése caudalisan. c) A nyaki fascia széles fronton történő stabilizálása a m. sternocleidomastoideus mentén. d) A nyak egészét jelképező modell csukott állapotban (intakt fascia)
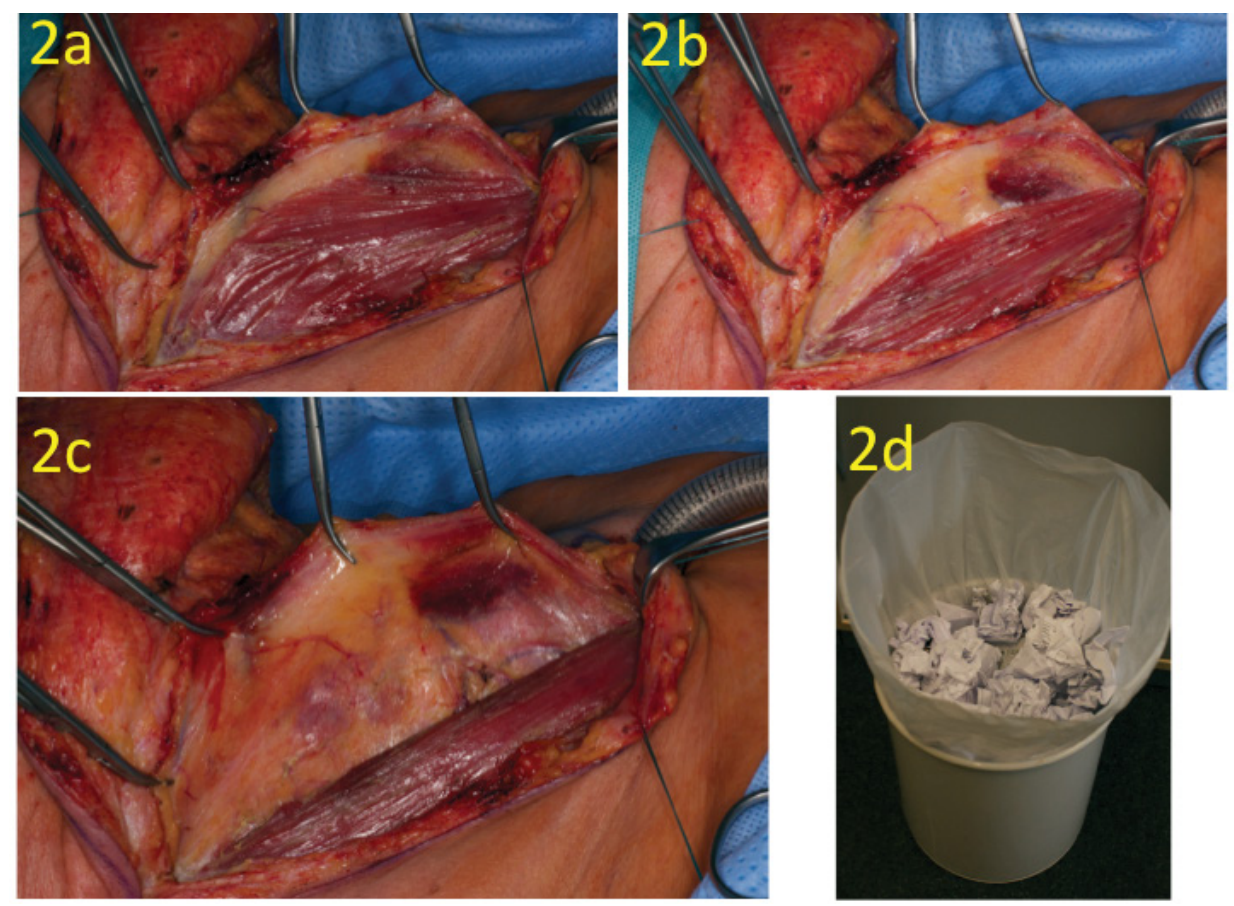

2. ábra

a) A nyaki fascia széles fronton történő preparálása a m. sternocleidomastoideus mentén. b) A nyaki fascia széles fronton történő preparálása lateralról medial felé haladva. c) A nyaki fascia széles fronton történő preparálása a medialis végponton. d) A nyak egészét jelképező modell nyitott állapotban (bemetszett fascia)

legyen a dissectio akár szelektív vagy komprehenzív kiterjedésű, akár elektív vagy terápiás indikációjú. Ezen kvalitatív koncepció lényege és eredménye nem az, hogy mütét közben megpróbáljunk még néhány nyirokcsomót azonosítani, hanem az összes, adott célrégióba tartozó nyirokcsomó elegáns és könnyed „en bloc” eltávo- lítása a releváns fasciacompartmentekből, strukturális kompromisszumok nélkül. A minőségi megközelítésen alapuló elv az eltávolított nyirokcsomók mennyiségi maximalizálására fordítható le, ráadásul úgy, hogy ez utóbbi az előbbinek nem célja, hanem természetes következménye [26]. 


\section{Nyaki dissectio az 1. csoportban-} „fascia unwrapping” (horizontális) módszer

Ezt a technikát típusosan lateralról medial felé haladva $(1 . a)-c) a ́ b r a)$, széles fronton történő preparálással (2. a)-c) ábra) végezzük úgy, hogy megfelelő szöveti trakció mellett a fasciaborítékban található összes nyirokés zsírszövetet disszekáljuk (3.a)-c) ábra) addig, amíg a vena jugularis interna elülső szélét elérjük a musculus digastricus hátsó hasa (a dissectio cranialis határa) és a clavicula (a dissectio caudalis határa) között. Amennyiben ezt megfelelően kivitelezzük, a kifejtett fasciaboríték tartalmazni fogja az összes releváns nyirokcsomót (4. a)-c) ábra). Ezen standardizált technika a fascia tartalmával ellentétben elsősorban az e tartalmat körülölelő fasciarétegekre fókuszál.
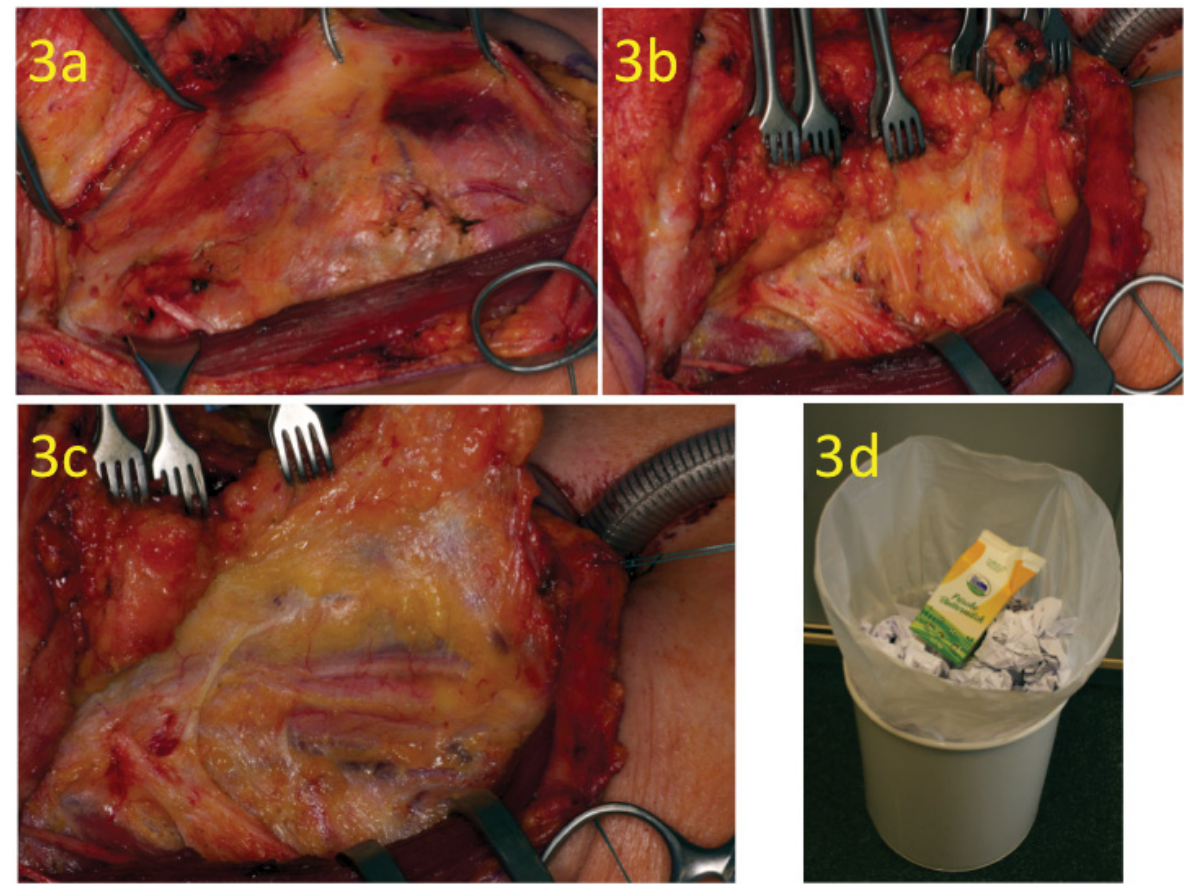

\begin{tabular}{l|l} 
3. ábra & a) A n. accessorius prezentálása a m. sternocleidomastoideus lateralizálása mellett. b) A plexus cervicalis prezentálása. c) A vagina carotica prezentálá-
\end{tabular} sa. d) A nyak egészét jelképező modell negatív és pozitív nyirokcsomókkal, a fascián belül

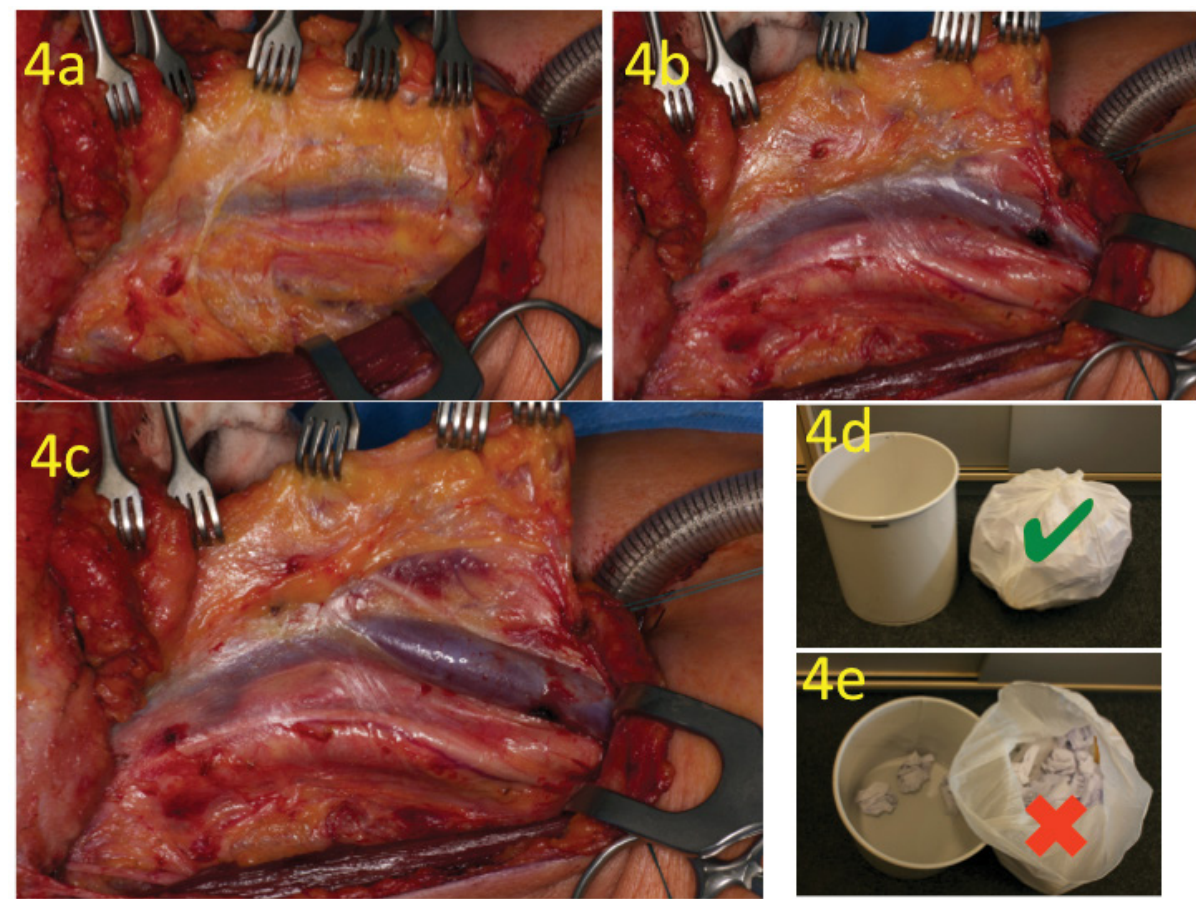

a) A fasciaborítékban lévô tartalom preparálása az a. carotis communis mentén. b) A fasciaborítékban lévő tartalom preparálása a n. vagus mentén. c) A fasciaborítékban lévő tartalom preparálása a v. jugularis interna mentén. d) A nyak egészét jelképező modell: optimális végeredmény. e) A nyak egészét jelképező modell: szuboptimális végeredmény 


\section{Nyaki dissectio a 2. csoportban- caudocranialis (vertikális) dissectio}

A caudocranialis irányban a fejbiccentő izom és a carotishüvely között végzett vertikális technika lényege, hogy a nyirok- és zsírszövetet - a IV/V. régiókban megragadva - a fontos nyaki képletekról preparáljuk le az I/II. régió felé haladva anélkül, hogy a nyaki fasciarétegeket célzottan kifejtenénk. Ez a technika a nyaki fasciacompartmentek helyett magára a nyirok-zsír szöveti tartalomra fókuszál.

\section{Sebészi team}

Annak érdekében, hogy minimálisra csökkentsük az egyes sebészek közötti potenciális minőségi különbségek eredményekre gyakorolt hatását, a betegeket egyenlően osztottuk el két tapasztalt fej-nyak sebész föorvos és négy szakorvos között. A fenti hat operatőr mindegyike 25 beteget operált $(6 \times 25=150)$, a beavatkozások fele (12 vagy 13) egyoldali, másik fele kétoldali nyaki dissectio volt. Ez összesen 36-39 nyaki dissectiónak felelt meg operatőrönként. Az egy fơre eső dissectiók során a két különböző technikát mindegyik sebész hozzávetőlegesen fele-fele arányban alkalmazva végezte. Azokban az esetekben, amikor szakorvos volt az operatőr, az egyik föorvos asszisztált.

\section{Statisztikai módszerek}

A két mütéti módszerrel nyert nyirokcsomók számának összehasonlításához többszintû, negatív binomiális regressziós modellt használtunk. A mütéti módszert, az adott nyaki régiót, a beteg nemét és a nyaki dissectio típusát független változókként határoztuk meg.

A fentieken kívül a mütéti módszer vs. nyaki régió vs. nyaki oldal elsődleges változók közötti minden kétirányú, valamint a háromirányú egymásra hatást szignifikáns eredmény esetén hozzáadtuk a modellhez (fordított elimináció módszere). Az illesztett átlagokat 95\%-os konfidenciaintervallummal ábrázoltuk. Az eredményt $\mathrm{p}<0,05$ szignifikanciaszint esetén fogadtuk el statisztikailag szignifikánsnak. Az elemzéseket a STATA13 (StataCorp., 2013) szoftverrel végeztük.

\section{Eredmények}

Az 1. és a 2. csoport nyaki dissectiói során nyert nyirokcsomók mennyiségét két különböző szinten hasonlítottuk össze: a nyirokcsomók számát nyaki régiónként és a teljes nyirokcsomóhozamot nyaki oldalanként.

\section{Statisztikai analízis}

\section{A nyirokcsomók számának összehasonlitása nyaki régiónként}

A régiónként begyưjitött nyirokcsomók átlagos száma az 1. csoportban 5,89 volt, 95\%-os konfidenciaintervallummal (CI) 5,33 és 6,44 közötti értékekkel; ugyanez a 2. csoportban 3,90 volt, 95\%-os CI-mal 3,47 és 4,33 közötti értékekkel. Ez 1,99 átlagos nyirokcsomó-mennyiségi különbséget jelent régiónként $(\mathrm{p}<0,001)$ (1. táblázat).

Az I., II., III. és IV. régiókban mért különbségek kiugróan szignifikánsak (csillaggal jelölve a táblázatban). Ugyanakkor kétféle magyarázattal is szolgálhatunk arra

1. táblázat |A nyirokcsomóhozam nyaki szintenkénti és a teljes hozam nyaki oldalankénti összehasonlítása

\begin{tabular}{|c|c|c|c|c|}
\hline & $\begin{array}{l}\text { 1. csoport } \\
\text { Horizontális dissectio } \\
\text { (fascia unwrapping) } \\
(95 \% \mathrm{CI})\end{array}$ & $\begin{array}{l}\text { 2. csoport } \\
\text { Vertikális dissectio } \\
\text { (caudocranialis) } \\
(95 \% \mathrm{CI})\end{array}$ & Különbség & p-érték \\
\hline \multicolumn{5}{|l|}{ 1. Nyaki szintenkénti összehasonlítás } \\
\hline Kumulatív átlag, egy szintre vetítve & $\begin{array}{l}5,89 \\
(5,33-6,44)\end{array}$ & $\begin{array}{l}3,90 \\
(3,47-4,33)\end{array}$ & 1,99 & $<0,001^{*}$ \\
\hline I. régió & $\begin{array}{l}3,38 \\
(2,74-4,01)\end{array}$ & $\begin{array}{l}1,67 \\
(0,99-2,35)\end{array}$ & 1,71 & $<0,001 *$ \\
\hline II. régió & $\begin{array}{l}6,80 \\
(5,89-7,71)\end{array}$ & $\begin{array}{l}4,61 \\
(3,87-5,36)\end{array}$ & 2,19 & $<0,001^{*}$ \\
\hline III. régió & $\begin{array}{l}6,06 \\
(5,23-6,89)\end{array}$ & $\begin{array}{l}3,77 \\
(3,14-4,40)\end{array}$ & 2,29 & $<0,001^{*}$ \\
\hline IV. régió & $\begin{array}{l}6,17 \\
(5,30-7,03)\end{array}$ & $\begin{array}{l}3,74 \\
(3,11-4,38)\end{array}$ & 2,43 & $<0,001^{*}$ \\
\hline V. régió & $\begin{array}{l}5,34 \\
(4,01-6,67)\end{array}$ & $\begin{array}{l}5,49 \\
(4,32-6,66)\end{array}$ & $-0,15$ & 0,868 \\
\hline \multicolumn{5}{|l|}{ 2. Nyaki oldalankénti összehasonlítás } \\
\hline $\begin{array}{l}\text { Teljes nyirokcsomóhozam nyaki } \\
\text { oldalanként }\end{array}$ & $\begin{array}{l}22,53 \\
(20,43-24,63)\end{array}$ & $\begin{array}{l}15,00 \\
(13,37-16,63)\end{array}$ & 7,53 & $<0,001^{*}$ \\
\hline
\end{tabular}


vonatkozóan, hogy miért nincs különbség az V. régióban. Egyfelől a mi tanulmányunkban viszonylag kevés $\mathrm{V}$. régiót érintő nyaki dissectio szerepelt, ezért valószínüsíthető, hogy az V. régióból származó nyirokcsomók tekintetében relatíve alacsony mintaszám állt rendelkezésre. A legtöbb szelektív nyaki dissectio nem tartalmazza az V. régiót.

Másfelől a „fasciakifejtéses” technika klinikailag N0 nyakon elsősorban a II., III. és IV. régiókban jelent módszertani eltérést a caudocranialis dissectióhoz képest: amint a dissectio rétege elkezd kibontakozni a fejbiccentő izom elülső éle mentén, úgy a horizontális technika nyirokcsomó-hozambeli előnye ezekre a lateralis régiókra koncentrálódik, és sokkal kevésbé az V. régióra.

Továbbá a tény, hogy az V. régió tekintetében nem volt különbség a két technika között, azt az indirekt következtetést engedi meg, hogy jelen összehasonlításunk valóban a sebészi technikák és nem az egyes sebészek között történt. A sebészek alapossága, tapasztalata vagy képzettségi szintje közötti esetleges különbség hatása ugyanis vélhetően minden nyaki régióban megfigyelhető lett volna.

Az I. régióban a „fasciakifejtés” elősegíti a submandibularis nyálmirigy körüli nyirokcsomók eltávolítását anélkül, hogy kockáztatnánk az arcideg marginális ágának épségét.

\section{Teljes nyirokcsomóbozam}

$\mathrm{Az}$ 1. csoportban a teljes nyirokcsomóhozam oldalankénti átlaga 22,53 nyirokcsomó volt, 95\%-os CI-vel, 20,43 és 24,63 közötti értékekkel. A 2. csoportban ugyanez az érték oldalanként 15,00 volt, 95\%-os CI-vel, 13,37 és 16,63 közötti értékekkel. A két csoport közti átlagosan 7,53 nyirokcsomó-hozambeli különbség szignifikáns volt $(\mathrm{p}<0,001)$ (1. táblázat).

\section{Megbeszélés}

Osvaldo Suárez és madridi tanítványa, César Gavilán (Javier Gavilán édesapja) az 1960-as években spanyolul publikálták munkájukat. Később Suárez egy másik tanítványa, az olasz Ettore Bocca volt az, aki az eredeti funkcionális koncepciót angolul publikálta (korrekt módon utalva Suárezre), és a „funkcionális nyaki dissectiót” angol nyelvterületen népszerúsítette az 1970-es és 1980-as években. Ezért észak-amerikai és brit sebészek az 1990es években az eljárást mint „Bocca-féle mütétet” kezdték tanítani az Egyesült Államokban és a Brit Nemzetközösség tagállamaiban. Ily módon az angolszász világra jellemző fellowship-alapú szuperspecializált fej-nyak sebészeti szakképzési rendszernek köszönhetően szélesebb körben is lehetővé vált ezen módszer mint intézményesített iskola elterjedése.

Az 1990-es és 2000-es évekre az eredetileg Suárez funkcionális koncepciójából kiinduló sebészi technika
- kulturális határokon átívelő hatásának köszönhetően az Egyesült Államokban és a Brit Nemzetközösség országaiban a szelektív nyaki dissectiók meghatározó módszerévé vált. Ezekben az országokban napjainkban ez jelenti az alapértelmezett sebészi technikát anélkül, hogy külön névvel illetnék: magától értetődően ezen lépések mentén haladva végzik a szelektív nyaki dissectiókat.

Ezzel szemben az európai kontinensen a szelektív nyaki dissectiókat fogalmi és tartalmi szempontból jelenleg is a módosított radikális nyaki dissectiók további módosításainak fogják fel: nem önálló funkcionális koncepcióként, hanem a George Crile által 1906-ban leírt radikális mútét többszöri módosításaként, illetve továbbfejlesztéseként. Ez utóbbit típusosan vertikálisan, azaz caudocranialis irányban végezték anélkül, hogy következetesen kifejtették volna a nyaki fascia rétegeit. Így az „európai”, azaz kontinentális szelektív nyaki dissectio megtartotta ezt a sebészi elvet, amelyet a brit-amerikai-ausztrál fellowship program néhány európai végzőse csupán sporadikusan tudott befolyásolni.

A vertikális irányú preparálással kivitelezett szelektív nyaki dissectio a nyirokcsomókat tartalmazó zsíros-kötőszövetes stromára összpontosít, azaz magára a tartalomra, mintsem a tartalom körüli borítéknak felfogható fasciára. Kissé talán profán, mégis kellően szemléletes megközelítés, ha a kötőszövetes-zsíros nyirokszövetre, azaz az eltávolítandó tartalomra mint háztartási hulladékra, a nyaki fasciára mint szemeteszsákra, az izmokra, idegekre és erekre pedig mint szemetesvödörre tekintünk. Ezen metafora mentén haladva a radikális nyaki dissectio során a teljes szemetesvödröt kidobjuk (1. d) ábra) - onkológiailag biztos megoldás, de túl nagy ára van. Ezzel szemben a fascia célzott kifejtésével végezve a nyaki dissectiót csak a szemeteszsákot dobjuk ki (2. d) és 3. d) ábra), annak teljes tartalmával együtt - onkológiailag hasonlóan biztos, de megörizzük az egyébként tiszta szemetesvödröt (4. d) ábra). Végül, ha vertikális irányban végezzük a szelektív nyaki dissectiót, először felszakítjuk a vödörben lévő szemeteszsákot, majd megkíséreljük kézzel kiüríteni a tartalmát. Egy bizonyos fokig így is sikeresek lehetünk, de a vödör óhatatlanul szennyezett marad - egyes, esetlegesen mikrometasztatikus nyirokcsomók visszamaradhatnak, ami szuboptimális nyirokcsomóhozamot eredményez (4. e) ábra).

A nyirokcsomóhozamot más tényezők is befolyásolják. Egyrészt az egyéni nyirokanatómia igen változatos, ezért az egyes konkrét betegekben rendelkezésre álló maximális nyirokcsomószám nem ismeretes [27]. Cadaverdissectiós adatok arra utalnak, hogy az I-V. nyaki régiókban oldalanként átlagosan legalább 30-40 nyirokcsomó távolítható el [28]. Másrészt a sebésznek a lehető legtöbb nyirokcsomót kell eltávolítania a megfelelő nyaki szintekból [29] azzal a céllal, hogy a begyüjtött nyirokcsomók száma minél jobban megközelítse az (egyébként ismeretlen) elérhetó nyirokcsomószámot. Itt jegyzendő meg, hogy a fiatal szakorvos operatőrök ebben a tanul- 
mányban jellemzően több nyirokcsomót gyưjtöttek be a „fasciakifejtéses” technikával, mint a tapasztalt föorvosok a vertikális technikával, valószínü tehát, hogy a helyes technika megfelelő alkalmazása fontosabb a puszta tapasztalatnál, illetve mútéti rutinnál. Végül a kórszövettani feldolgozás alapossága is jelentősen befolyásolja a patológus által dokumentált nyirokcsomószámot. Az utóbbi az egyetlen olyan információ, amelyet a klinikai döntési folyamat során felhasználhatunk, annak tudatában is, hogy minden egyes idevezető lépés elkerülhetetlenül bizonyos adatvesztéssel jár.

Bár a terápiás döntések - például adjuváns kezelés javaslata vagy elhagyása - csak a dokumentált nyirokcsomószámon alapuló staginginformáción nyugodhatnak, a betegség lefolyását és végső soron a beteg sorsát a valóban eltávolított nyirokcsomók száma befolyásolja. Még ha egy eltávolított, klinikailag-radiológiailag negatívnak tûnő, de valójában mikrometasztatikus nyirokcsomó el is kerüli a patológus figyelmét [12], mégsem maradt a betegben, aki így nagyobb valószínúséggel marad tumormentes, függetlenül az esetleg helytelenül pN0-ként dokumentált nyaki státusztól és az ennek megfelelően elmaradt adjuváns kezeléstől [12].

Egy klinikailag $\mathrm{N}+$ nyak terápiás indikációjú mútétje során addig biztonságos a funkcionális és szelektív nyaki dissectio végzése a „fasciakifejtés” technikájával, amíg nincs makroszkópos ECS. Elektíven operált cN0 nyak esetén a magasabb nyirokcsomóhozam - amely információt a nyaki dissecatum kórszövettani vizsgálata szolgáltatja - növeli a stádiummeghatározás megbízhatóságát. $\mathrm{Az}$ onkológiai biztonság és a jobb életminőség között egyensúlyozva szükséges azonosítani azon alacsony kockázatú betegeket, akiknél nem feltétlenül szükséges adjuváns kezelés, vagyis a valódi N0 betegeket. Ezért a nyirokcsomóhozam ismerete és figyelembevétele kiemelt jelentőségű, amennyiben az adjuváns terápia elhagyásáról szóló döntés egy elektíven elvégzett szelektív nyaki dissectio alapján vélelmezett pN0 stádiumon nyugszik.

Tanulmányunk kimutatta, hogy a funkcionális nyaki dissectio sebészi koncepciója - ennek eredeti funkcionális értelmében - és az ebből levezetett és standardizált mütéti technika, a „fasciakifejtés” sebészi módszere szignifikánsan jobb eredményt szolgáltat a nyirokcsomóhozam tekintetében, ezért növeli az onkológiai biztonságot. A folyamatosan növekvő egészségügyi költségek korában a sebészi gondolkodásmódban és a dissectiós technikában történő egyszerű változtatás - amelyet bármely operatőr anyagi ráfordítás nélkül megvalósíthat - legalább annyira szolgálhatja az onkológiai betegek javát, mint a költséges high-tech fejlesztések.

Anyagi támogatás: A közlemény megírása anyagi támogatásban nem részesült.

Szerzői munkamegosztás: H. I.: A kézirat megírása. G. I.: A kézirat ellenőrzése, javítása. L. L.: A vonatkozó iroda- lom gyưjtése, a kézirat ellenőrzése. L. B. B.: A koncepció kidolgozása, adatgyújtés, statisztika, végső ellenőrzés. A kézirat végleges változatát valamennyi szerző elolvasta és jóváhagyta.

Érdekeltségek: A szerzőknek nincsenek releváns érdekeltségeik. L. B. B. az Intuitive Surgical, Inc. (daVinci robot) és az Olympus Europe (Thunderbeat) tanácsadója és oktatója.

\section{Irodalom}

[1] Le Voyer, T. E., Sigurdson, E. R., Hanlon, A. L., et al.: Colon cancer survival is associated with increasing number of lymph nodes analyzed: a secondary survey of intergroup trial INT-0089. J. Clin. Oncol., 2003, 21(15), 2912-2919.

[2] Chen, S. L., Bilchik, A. J.: More extensive nodal dissection improves survival for stages I to III of colon cancer: a populationbased study. Ann. Surg., 2006, 244(4), 602-610.

[3] Cianchi, F., Palomba, A., Boddi, V., et al.: Lymph node recovery from colorectal tumor specimens: recommendation for a minimum number of lymph nodes to be examined. World J. Surg., 2002, 26(3), 384-389.

[4] Brunocilla, E., Pernetti, R., Schiavina, R., et al.: The number of nodes removed as well as the template of the dissection is independently correlated to cancer-specific survival after radical cystectomy for muscle-invasive bladder cancer. Int. Urol. Nephrol., 2013, 45(3), 711-719.

[5] Herr, H. W., Bochner, B. H., Dalbagni, G., et al.: Impact of the number of lymph nodes retrieved on outcome in patients with muscle invasive bladder cancer. J. Urol., 2002, 167(3), 12951298.

[6] Konety, B. R., Joslyn, S. A., O'Donnell, M. A.: Extent of pelvic lymphadenectomy and its impact on outcome in patients diagnosed with bladder cancer: analysis of data from the Surveillance, Epidemiology and End Results Program data base. J. Urol., 2003, 169(3), 946-950.

[7] Briganti, A., Chun, F. K., Salonia, A., et al.: Critical assessment of ideal nodal yield at pelvic lymphadenectomy to accurately diagnose prostate cancer nodal metastasis in patients undergoing radical retropubic prostatectomy. Urology, 2007, 69(1), 147151.

[8] Johnson, T. V., Hsiao, W., Delman, K. A., et al.: Extensive inguinal lymphadenectomy improves overall 5-year survival in penile cancer patients: results from the Surveillance, Epidemiology, and End Results Program. Cancer, 2010, 116(12), 2960-2966.

[9] Peyre, C. G., Hagen, J. A., DeMeester, S. R., et al.: The number of lymph nodes removed predicts survival in esophageal cancer: an international study on the impact of extent of surgical resection. Ann. Surg., 2008, 248(4), 549-556.

[10] Volpe, C. M., Driscoll, D. L., Douglass, H. O. Jr.: Outcome of patients with proximal gastric cancer depends on extent of resection and number of resected lymph nodes. Ann. Surg. Oncol., 2000, 7(2), 139-144

[11] Weir, L., Speers, C., D’Yachkova, ., et al.: Prognostic significance of the number of axillary lymph nodes removed in patients with node-negative breast cancer. J. Clin. Oncol., 2002, 20(7), 17931799.

[12] Jaber, J. J., Zender, C. A., Mebta, V., et al.: Multi-institutional investigation of the prognostic value of lymph nodel yield in advanced-stage oral cavity squamous cell carcinoma (OCSCC). Head Neck, 2014, 36(10), 1446-1452.

[13] Pereira, J. A., Jimeno, J., Miquel, J., et al.: Nodal yield, morbidity, and recurrence after central neck dissection for papillary thyroid carcinoma. Surgery, 2005, 138(6), 1095-1100. (Discussion 1100-1101.) 
[14] Vas Nunes, J. H., Clark, J. R., Gao, K., et al.: Prognostic implications of lymph node yield and lymph node ratio in papillary thyroid carcinoma. Thyroid Off. J. Am. Thyroid Assoc., 2013, 23(7), 811-816.

[15] Ebrabimi, A., Zhang, W. J., Gao, K., et al.: Nodal yield and survival in oral squamous cancer: defining the standard of care. Cancer, 2011, 117(13), 2917-2925.

[16] Patel, S. G., Amit, M., Yen, T. C., et al.: Lymph node density in oral cavity cancer: results of the International Consortium for Outcomes Research. Br. J. Cancer, 2013, 109(8), 2087-2095.

[17] Agrama, M. T., Reiter, D., Cunnane, M. F., et al.: Nodal yield in neck dissection and the likelihood of metastases. Otolaryngol. Head Neck Surg., 2003, 128(2), 185-190.

[18] Ebrahimi, A., Clark, J. R, Amit, M., et al.: Minimum nodal yield in oral squamous cell carcinoma: defining the standard of care in a multicenter international pooled validation study. Ann. Surg. Oncol., 2014, 21(9), 3049-3055.

[19] Yu, Y., Wang, X. L., Xu, Z. G., et al.: Prognostic value of the number of lymph nodes retrieved after selective neck dissection in hypopharyngeal squamous carcinoma. Zhonghua er bi yan hou tou jing wai ke za zhi. Chin. J. Otorhinolaryngol. Head Neck Surg., 2013, 48(2), 148-153

[20] Bhattacharyya, N.: The effects of more conservative neck dissections and radiotherapy on nodal yields from the neck. Archiv. Otolaryngol. Head Neck Surg., 1998, 124(4), 412-416.

[21] Gavilán, J.: Functional and selective neck dissection. Thieme Verlag, New York, 2002.

[22] Ferlito, A., Gavilán, J., Buckley, J. G., et al.: Functional neck dissection: fact and fiction. Head Neck, 2001, 23(9), 804-808.
[23] Gavilán, J., Gavilán, C., Herranz, J.: Functional neck dissection: three decades of controversy. Ann. Otol. Rhinol. Laryngol., 1992, 101(4), 339-341.

[24] Kerawala, C. J., Bisase, B., Hopper, A.: Is total nodal yield in neck dissections influenced by the method of specimen presentation to the pathologist? Br. J. Oral Maxillofac. Surg., 2009, 47(5), 360-362.

[25] Upile, T., Jerjes, W., Nouraei, S. A., et al.: How we do it: a method of neck dissection for histopathological analysis. BMC Surg., 2007, 7, 21.

[26] Gavilán, C., Gavilán, J.: Five-year results of functional neck dissection for cancer of the larynx. Arch. Otolaryngol. Head Neck Surg., 1989, 115(10), 1193-1196.

[27] Norling, R., Therkildsen, M. H., Bradley, P. J., et al.: Nodal yield in selective neck dissection. Acta Otolaryngol., 2013, 133(9), 965-971.

[28] Friedman, M., Lim, J. W., Dickey, W., et al.: Quantification of lymph nodes in selective neck dissection. Laryngoscope, 1999, 109(3), 368-370.

[29] Morton, R. P., Gray, L., Tandon, D. A., et al.: Efficacy of neck dissection: are surgical volumes important? Laryngoscope, 2009, $119(6), 1147-1152$.

(Lőrincz Balázs Bendegúz dr., Martini str. 52., D-20246 Hamburg, Németország, e-mail: b.loerincz@uke.de)

\section{ÁLLÁSAJÁNLAT}

Az országhatár mellett, az Örség és a Vendvidék kapujában, főleg schizophren betegek ellátására szakosodott 740 fös intézmény keres főállású pszichiátert közalkalmazotti jogviszonyban történő munkavégzésre. Amennyiben más jogviszony keretében kíván munkát vállalni, kérjük, jelezze azt a foglalkoztatás jellegének megjelölésével.

Pszichoterápiás irányultság, pszichiátriai szakvizsga szükséges.

A munkaidő heti 40 óra. Térítés ellenében $80 \mathrm{~m}^{2}$-es szolgálati lakást tudunk biztosítani.

\section{Cím: Pszichiátriai Betegek Otthona Szentgotthárd}

9970 Szentgotthárd, Hunyadi u. 29.

\section{Kapcsolattartó: Takácsné Hargitai Beáta}

Tel.: 06/94/552-560; e-mail: gotthszo@t-online.hu 